\title{
Investigating the effect of different green marketing on brand loyalty
}

\author{
Naser Azad, Seyed Mohsen Mahmoudzadeh*, Seyed Shahab Mousavi, Elham Agha Alikhani and Saba \\ Kamali
}

Department of Management, Islamic Azad University, South Tehran Branch, Tehran, Iran

\begin{tabular}{l}
\hline C H R O N I C L E \\
\hline Article history: \\
Received May 22, 2013 \\
Received in revised format \\
12 August 2013 \\
Accepted 7 September 2013 \\
Available online \\
September 12 2013 \\
\hline Keywords: \\
Green marketing \\
Green promotion \\
Green pricing \\
Green distribution
\end{tabular}

\section{A B S T R A C T}

\begin{abstract}
Green marketing plays important role on developing different business plans without harming environment. Green marketing may also help us find more loyal customers since many people do care about taking care of environment and prefer purchasing only green products and services. In this paper, we present an empirical investigation to find the effect of different green strategies on brand loyalty. The proposed study designs a questionnaire and distributes it among 384 randomly selected people who purchase various brands in city of Tehran, Iran. The gathered data are analyzed using structural equation modeling and the results indicate that different green marketing strategies including green pricing, green promotion, green distribution positively influence brand loyalty.
\end{abstract}

\section{Introduction}

During the past few years, there have been tremendous changes on our planet due to an increase on world's temperature. Global warming has created drought in some regions and it has caused many floods, tornados, hurricane, etc. in other places. In such events, there have been tremendous efforts on behalf of business owners, societies, governments and people all over the world to reduce the effect of global warming. Industry owners try to use materials with less harmful effects on our planet. Many industries try to introduce green products and use the terms of green pricing, green distribution and green promotion to build an environment friendly products (Xu et al., 2013).

There are many attempts on green marketing planning. Vazifehdoust et al. (2013), for instance, proposed an integrated model that integrated the Theory of Reasoned Action (TRA) and two groups of variables, personal and marketing, to study the attitudinal and behavioral decision factors to purchase green products. The model derived and examined via structural equation modeling on a sample of 374 consumers from the Guilan province in Iran. The results demonstrated that attitude was 
explained by consumers' environmental concern, quality of green products, green advertising and green labeling. The results of the structural equation analysis indicated that behavior positively impacted intention to purchase green products. Green purchasing intention also affected on green purchasing behavior.

According to Vijaya Ramnath et al. (2011), with globalization, sweeping technological development, and increasing competition, customers are placing bigger demands on manufacturers to increase quality, flexibility and on time delivery of products. Therefore, manufacturers ought to develop and keep a high degree of coherence among competitive priorities, order winning criteria and improvement activities. The production managers are making significant attempt to transform their organization by using familiar and beneficial management philosophies like cellular manufacturing $(\mathrm{CM})$, lean manufacturing (LM), green manufacturing (GM), total quality management (TQM), agile manufacturing (AM), and just in time manufacturing (JIT). Vijaya Ramnath et al. (2011) proposed an optimal assembly technique for an engine manufacturer's assembly line in India. They reported that in order to reduce the above mentioned wastes, lean kitting assembly could be implemented.

According to Sofiyabadi et al. (2010), employment of supply chain management could influence the entire functional and practical aspects of industry and services positively and it could make significant change on the manager's attitude towards the implementation of supply chain management systems from a cost-oriented attitude to an enabling attitude towards better activities with other chain members. Yet still many firms do not have the required vision within the identification of strategic appropriate measure in implementation, evaluation and usage of proper benchmarks to reach an integrated chain. Constantly supply chain management activity can be introduced as a tied up with strategic level of organization.

According to Liu et al. (2012) green marketing and sustainable supply chain management should be seamlessly integrated so that green customer's requirements could be better met by the supply chain capabilities. Liu et al. (2012) proposed a new hub-and-spoke integration model to integrate green marketing and sustainable supply chain management from six dimensions including product, promotion, planning, process, people and project. Their new integration model permitted the flows of resources such as information, materials and funds between green marketing and sustainable supply chain management through multiple direct pathways. Wang et al. (2013) developed green management standards for restaurants in an application of green supply chain management. Shang et al. (2010) provided taxonomy of green supply chain management capability among electronicsrelated manufacturing firms in Taiwan. Diabat and Govindan (2011) developed an analysis of the drivers influencing the implementation of green supply chain management. Zhang and Zhao (2012) discussed the principles of green packaging, and from the two levels of government and enterprises, we put forward a specific management strategy.

\section{The proposed study}

In this paper, we present an empirical investigation to find the effect of different green strategies on brand loyalty. There are 10 hypotheses associated with the proposed study of this paper as follows,

1. Green product has meaningful effect on customer loyalty in different brands.

2. Green pricing has meaningful effect on customer loyalty in different brands.

3. Green promotion has meaningful effect on customer loyalty in different brands.

4. Green distribution has meaningful effect on customer loyalty in different brands.

5. There is a meaningful relationship between green product and green pricing. 
6. There is a meaningful relationship between green product and green promotion.

7. There is a meaningful relationship between green product and green distribution.

8. There is a meaningful relationship between green pricing and green promotion.

9. There is a meaningful relationship between green pricing and green distribution.

10. There is a meaningful relationship between green promotion and green distribution.

The proposed study of this paper designs two questionnaires where the first one measures integrated green marketing and the second one looks for the effects of green loyalty. We distributed 40 questionnaires among some experts and Cronbach alphas have been calculated as 0.823 and 0.931 for two mentioned questionnaires, respectively. The sample size is calculated as follows,

$$
N=Z_{\alpha / 2}^{2} \frac{p \times q}{e^{2}},
$$

where $N$ is the sample size, $p=1-q$ represents the probability, $z_{\alpha / 2}$ is CDF of normal distribution and finally $\varepsilon$ is the error term. For our study we assume $p=0.5, z_{\alpha / 2}=1.96$ and $e=0.99$, the number of sample size is calculated as $N=384$. The proposed study designs a questionnaire and distributes it among 384 randomly selected people who purchase various brands in city of Tehran, Iran. In our survey, $52 \%$ of the participants were male and the remaining $48 \%$ were female. In addition, $64 \%$ of the participants were married and the remaining 36\% were single. Fig. 1 shows all personal characteristics of the participants.

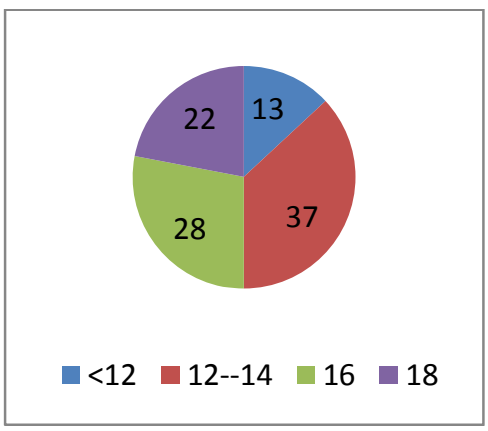

Years of education

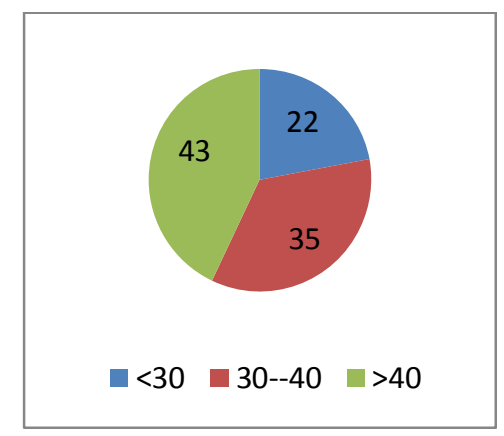

Age

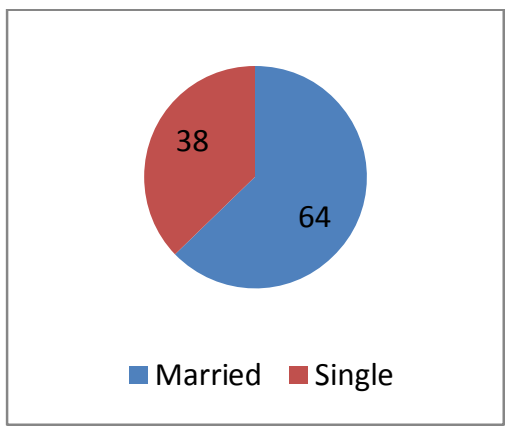

Marital status

Fig. 1. Personal characteristics of the participants

As we can observe from the results of Fig. 1, people who participated in our survey were highly educated and mostly middle age. Table 1 demonstrates mean and standard deviation of the main components of the survey.

\section{Table 1}

Mean and standard deviation of the main components of the survey

\begin{tabular}{lcc}
\hline Component & Mean & Standard deviation \\
\hline Customer loyalty & 2.56 & 0.81 \\
Green product & 3.12 & 0.86 \\
Green price & 2.31 & 0.66 \\
Green distribution & 2.66 & 0.76 \\
Green promotion & 2.23 & 0.63 \\
\hline
\end{tabular}

Next, we look for Pearson correlation ratios between different components of green marketing. Table 2 demonstrates the summary of our findings. 
Table 2

The summary of Pearson correlation ratios among different components of the survey

\begin{tabular}{lcc}
\hline Component & Value & Sig. \\
\hline There is a relationship between green product and green pricing. & 0.56 & 0.000 \\
There is a relationship between green product and green distribution. & 0.46 & 0.000 \\
There is a relationship between green product and green promotion. & 0.32 & 0.004 \\
There is a relationship between green pricing and green distribution. & 0.54 & 0.000 \\
There is a relationship between green pricing and green promotion. & 0.39 & 0.001 \\
There is a relationship between green promotion and green distribution. & 0.55 & 0.000 \\
\hline
\end{tabular}

As we can see from the results of Table 2, there are some positive and meaningful relationships between different components of green product and green pricing, green distribution and green promotion. The biggest correlation belongs to relationship between green product and green pricing while the minimum correlation belongs to the relationship between green product and green promotion.

\section{Structural equation modeling}

In this section, we present details of our survey on testing various hypotheses based on the implementation of structural equation modeling. Fig. 2 shows details of our survey on testing various hypotheses of the survey.

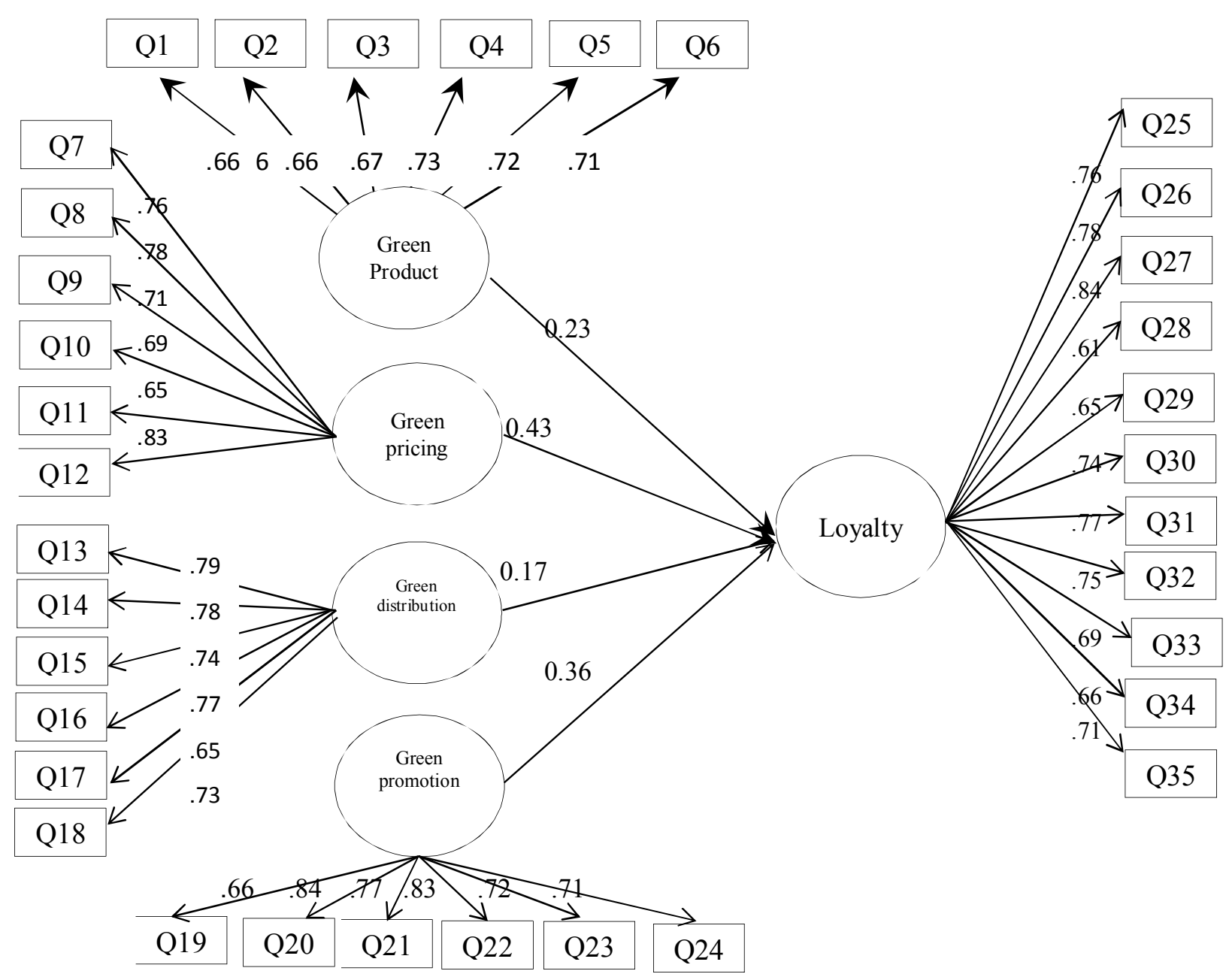

Fig. 2. The results of structural equation modeling 
The results of statistical observation associated with the implementation of LISREL software package is summarized in Table 3 as follows,

Table 3

The summary of statistical observations

\begin{tabular}{cccccccc}
\hline CFI & AGFI & GFI & RMSEA & Chi-Square/df & df & P-value & Chi-Square \\
\hline 0.89 & 0.84 & 0.91 & 0.059 & 1.91 & 171 & 0.000 & 292 \\
\hline
\end{tabular}

The results of Table 3 show that all statistical observations are within acceptable limits and we can confirm the results of structural equation modeling when the level of significance is five percent and Table 4 summarizes the results of our findings.

Table 4

The summary of testing various hypotheses

\begin{tabular}{lccc}
\hline Component & coefficient & t-value & Result \\
\hline Green product influences positively on customer loyalty. & 0.23 & 5.88 & $\sqrt{ }$ \\
Green price influences positively on customer loyalty. & 0.43 & 10.18 & $\sqrt{ }$ \\
Green distribution influences positively on customer loyalty. & 0.17 & 3.55 & $\sqrt{ }$ \\
Green promotion influences positively on customer loyalty. & 0.36 & 7.25 & $\sqrt{ }$ \\
\hline
\end{tabular}

\section{Discussion and conclusion}

Today, there is no doubt that human nature has influenced environment, significantly. Our planet is steadily getting warm and within few decades, the world will face substantial changes. There are many attempts to help industry become more environments friendly and this has created motivation for better marketing planning. As people become more aware about the effects of green marketing planning, more people decide to only purchase products and services, which are helping environment and do not harm out planet. Therefore, there may be some relationship between green product and customer loyalty. In this paper, we have presented an empirical investigation to study the relationship between green product, green pricing, green distribution and green promotion with customer loyalty in different brands sold in city of Tehran, Iran. The proposed study has applied Pearson correlation ratios as well as structural equation modeling and the results of our survey have confirmed that green product, price, distribution and promotion positively influence customer loyalty. The biggest impact belongs to the relationship between green price and customer loyalty (coefficient $=0.43$ ), followed by the relationship between green promotion and customer loyalty (coefficient $=0.36$ ) and the relationship between green product and customer loyalty (coefficient $=0.23$ ).

\section{Acknowledgement}

The authors would like to thank the anonymous referees for constructive comments on earlier version of this paper.

\section{References}

Diabat, A., \& Govindan, K. (2011). An analysis of the drivers affecting the implementation of green supply chain management. Resources, Conservation and Recycling, 55(6), 659-667.

Liu, S., Kasturiratne, D., \& Moizer, J. (2012). A hub-and-spoke model for multi-dimensional integration of green marketing and sustainable supply chain management Original. Industrial Marketing Management, 41(4), 581-588. 
Shang, K.C., Lu, C.S., \& Li, S. (2010). A taxonomy of green supply chain management capability among electronics-related manufacturing firms in Taiwan. Journal of Environmental Management, 91(5), 1218-1226.

Sofiyabadi, J., Movahedi, M., \& Noori Nasab, S. (2010). Strategic orientation in evaluation of supply chain activities. Management Science Letters, 2(5), 1785-1794.

Vazifehdoust, H., Taleghani, M., Esmaeilpour, F., \& Nazari, K. (2013). Purchasing green to become greener: Factors influence consumers' green purchasing behavior. Management Science Letters, 3(9), 2489-2500.

Vijaya Ramnath, B., Elanchezhian, C., \& Kesavan, R. (2011). A multi attribute decision making method for selection of optimal assembly line. Management Science Letters, 1(1), 65-72.

Wang, Y.F., Chen, S.P., Lee, Y.C., \& Tsai, C.T. (2013). Developing green management standards for restaurants: An application of green supply chain management. International Journal of Hospitality Management, 34, 263-273.

Xu, L., Mathiyazhagan, K., Govindan, K., Noorul Haq, A., Vyas Ramachandran, N., \& Ashokkumar, A. (2013). Multiple comparative studies of Green Supply Chain Management: Pressures analysis. Resources, Conservation and Recycling, 78, 26-35.

Zhang, G., \& Zhao, Z. (2012). Green packaging management of logistics enterprises. Physics Procedia, 24(B), 900-905. 